Review Article

\title{
Sargassum Invasion of Coastal Environments: A Growing Concern
}

\author{
Clifford Louime, Jodany Fortune and Gary Gervais \\ Department of Environmental Sciences, University of Puerto Rico Rio Piedras, San Juan, Puerto Rico
}

\author{
Article history \\ Received: 01-12-2016 \\ Revised: 11-01-2017 \\ Accepted: 06-02-2017 \\ Corresponding Author: \\ Clifford Louime \\ Department of Environmental \\ Sciences, University of Puerto \\ Rico Rio Piedras, San Juan, \\ Puerto Rico \\ Email: Cliford.Louime@upr.edu
}

\begin{abstract}
Floating tropical brown macroalgae, commonly called Sargassum, besieging the Caribbean coastlines have long been a regular occurrence in the region, especially during the fall and winter months. These washed-up seaweeds are considered by scientists as an important part of the coastal ecosystem, as they serve as habitat and nurseries for numerous marine species. However, in recent years, the region has seen an explosion in Sargassum densities with unusually high extent and frequency. This natural catastrophe, as some label the 2013 invasion, has even crossed the Atlantic Ocean to reach the west coast of Africa. Some scientists have linked this disaster with global climate change and the concomitant higher than normal temperatures. Now the question is being raised as to whether the latest seen invasion of Sargassum represents a seasonal anomaly or a regime shift in ocean currents and climate. Therefore, it is urgent for the scientific community to understand the causes of these recent occurrences and provide potential remedial solutions, as these invasions could have significant negative impacts on marine ecosystems, even disrupting entire economic activities of local communities.
\end{abstract}

Keywords: Sargassum, Climate Change, Marine Ecosystems, Algae, Bioenergy

\section{Introduction}

\section{Origin of the Sargassum}

Periodically, mats of brown algae drift along the coastlines of most Caribbean island nations. This phenomenon happens basically every winter, when trade winds are usually strong in the region, driving great amount of drifts to the coast (Gavio et al., 2015). These algae are of two species, namely Sargassum fluitans and Sargassum natans (Fig. 1) (Moreira and Alfonso, 2013). These are pelagic algae that grow in the open sea without a sound clip. Usually a strong presence of these algae is noticed in the region called the Sargasso Sea (Sargazzo the Italian word for seaweed). The Sargasso Sea has always been considered as the principal source of these golden tides of pelagic Sargassum. This is a region in the North Atlantic Ocean, between the meridians $70^{\circ}$ and $40^{\circ} \mathrm{W}$ and the parallels $25^{\circ}$ and $35^{\circ} \mathrm{N}$ (Laffoley, 2011). It is the only sea without a shoreline. Its boundaries are formed by the North Atlantic Drift to the north, the Gulf Stream to the west, the Canary Current to the east and north equatorial current in the south (Fig. 2)
(Laffoley, 2011). Its total area-although variable - is 3,500,000 square kilometers (Laffoley, 2011). This region is characterized by the frequent absence of wind currents on the one hand and the abundance of plankton on the other (Laffoley, 2011). The waters in this space operate in a slow circular motion and all floating objects drift between these limits (Laffoley, 2011).

Over the past few decades, the volume of these floating algae that washed-up along the Caribbean coastlines has been increasing (Johnson et al., 2013). A huge Sargassum increase documented by Smetacek and Zingone (2013) in the Gulf of Mexico in the 90s, was traced back to higher nutrient loads discharged into the Mississippi river. In another study conducted by Gower and King (2011), such an unprecedented amount of seaweed was surveyed in the Gulf of Mexico, that it prompted regulators to label 2005 as the "Sargassum Year". This study, published in 2013, revealed that the huge amount of brown tides seen in the Gulf in 2005 and 2011 actually originated from there and not from the Sargasso Sea as previously thought (Gower et al., 2013). An estimated 1 million tons of algal biomass are 
transported from the gulf to the Sargasso Sea every spring. By 2011, Sargassum biomass drifts in the Caribbean region reached a peak, by recording a 200fold higher biomass than the previous eight years. That was also the first time in recent memory, that washed-up Sargassum reached the coast of Africa (Smetacek and Zingone, 2013). Johnson et al. (2013) reported unprecedented amounts of pelagic seaweed were washed ashore along the Western coastline of Africa (Fig. 3).

\section{Underlying Causes of the Sargassum Invasion}

Several hypotheses have been put forward, trying to address this question. According to several sources, global climate change might have forced the Sargasso Sea to move further south, bringing the seaweeds closer to the Caribbean Sea (Valesco, 2015; Sargeant, 2015). Some others linked the Sargassum invasion to the lack of cyclones in the region during the last decade (http://coastalcare.org/sections/inform/page/4/). This seems to create optimal conditions for the growth of algae. In addition, the deviation of the Gulf Stream to the south promotes an influx of algae in the Caribbean (http://ambergriscaye.com/forum/ubbthreads.php/topics/ 506881/the-journey-of-the-sargassum.html). A third school of thought considers the increased intake of nutrient-rich Sahara dust (including $\mathrm{Fe}, \mathrm{K}$ and phosphate) as one of the major drivers facilitating the growth of algae in the sea (Moanga, 2015). The fourth hypothesis attributes the Sargassum invasion to nutrient overload resulting from deforestation of the Amazon basin in Brazil (http://www.newsweek.com/2015/07/10/sargassumruining-beaches-texas-tobago-347735.html). In fact, because of deforestation, the amazon river spoof tons of organic matter and nutrients to the sea thus promoting excessive growth of algae. They advanced the hypothesis of high flow of nutrients from South America's Amazon and Orinoco Rivers mixing with warmer ocean temperatures as the basis for this harmful algal bloom (http://www.newsweek.com/2015/07/10/sargassumruining-beaches-texas-tobago-347735.html).

The scientific community does not subscribe unanimously to all these assumptions. However, nutrient discharge from the Amazon river seems to be the most plausible cause. In fact, new studies have shown the formation of a small 'Sargasso Sea' 'in eastern Brazil with an algae tail dragging all the way to the West-Indies (Gower and King, 2008). e.g., Jim Gower and Stephanie King of Institute of Ocean Sciences (IOS) in their 2008 publication entitled "Satellite Images Show the Movement of Floating Sargassum in the Gulf of Mexico and Atlantic Ocean" used satellite imagery to present the first mapping of the full distribution and movement of the population of Sargassum in the Gulf of Mexico and western Atlantic in the years 2002 to 2008 (Gower and King, 2008).

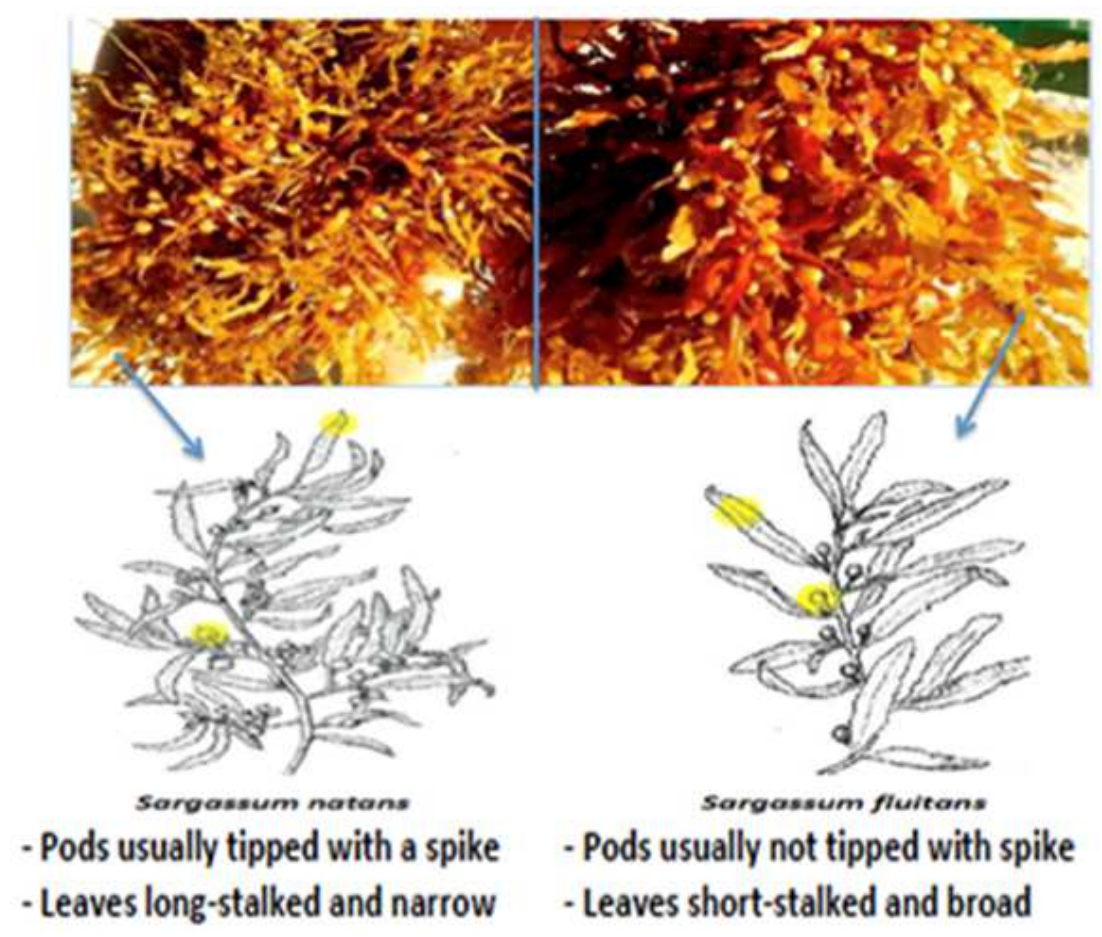

Fig. 1. Sargassum fluitans (left) and Sargassum natans (right) - Sources: Morphology of Sargassum fluitans and de S. natans (Doyle and Franks, 2015; Le Lann, 2009) 


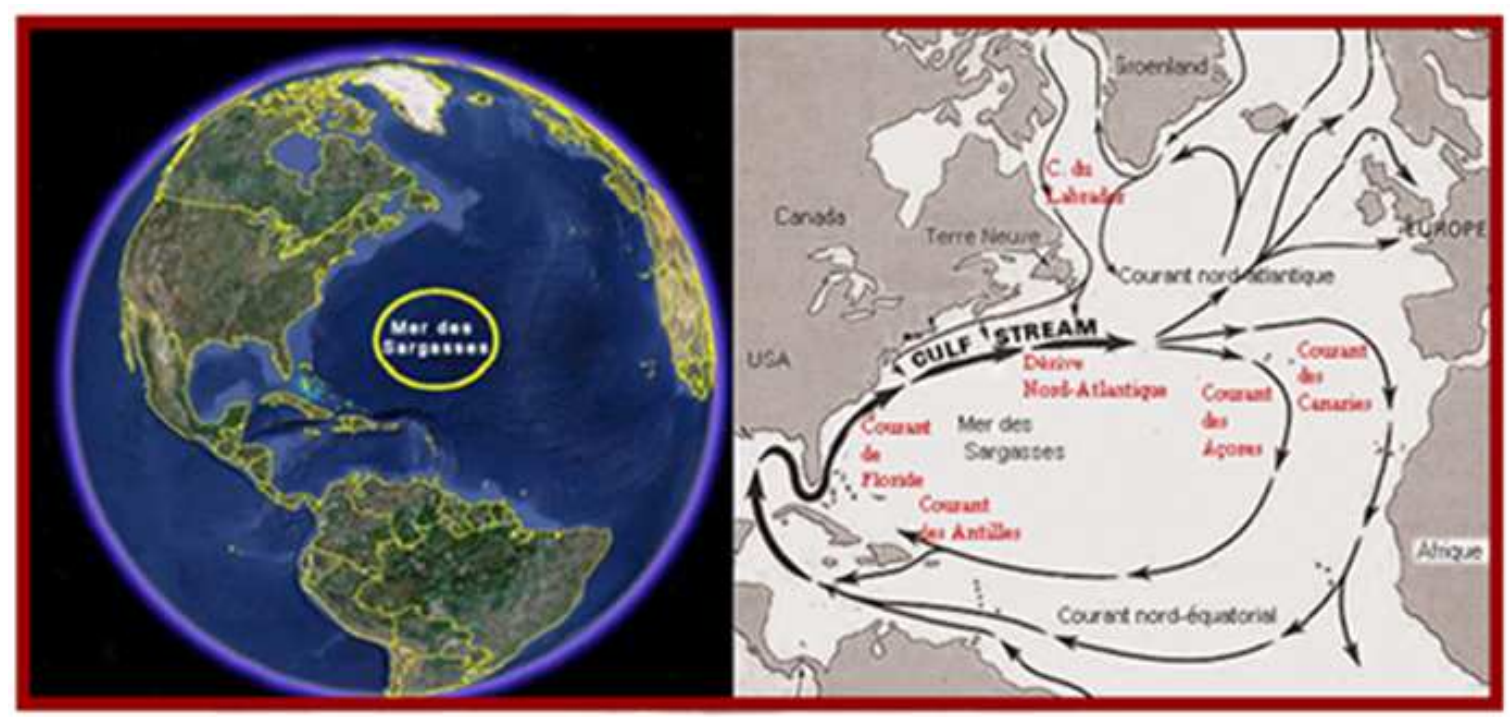

Fig. 2. http://wwz.ifremer.fr/guyane/content/download/41806/569470/file/Sargasses\%20Guyane.pdf

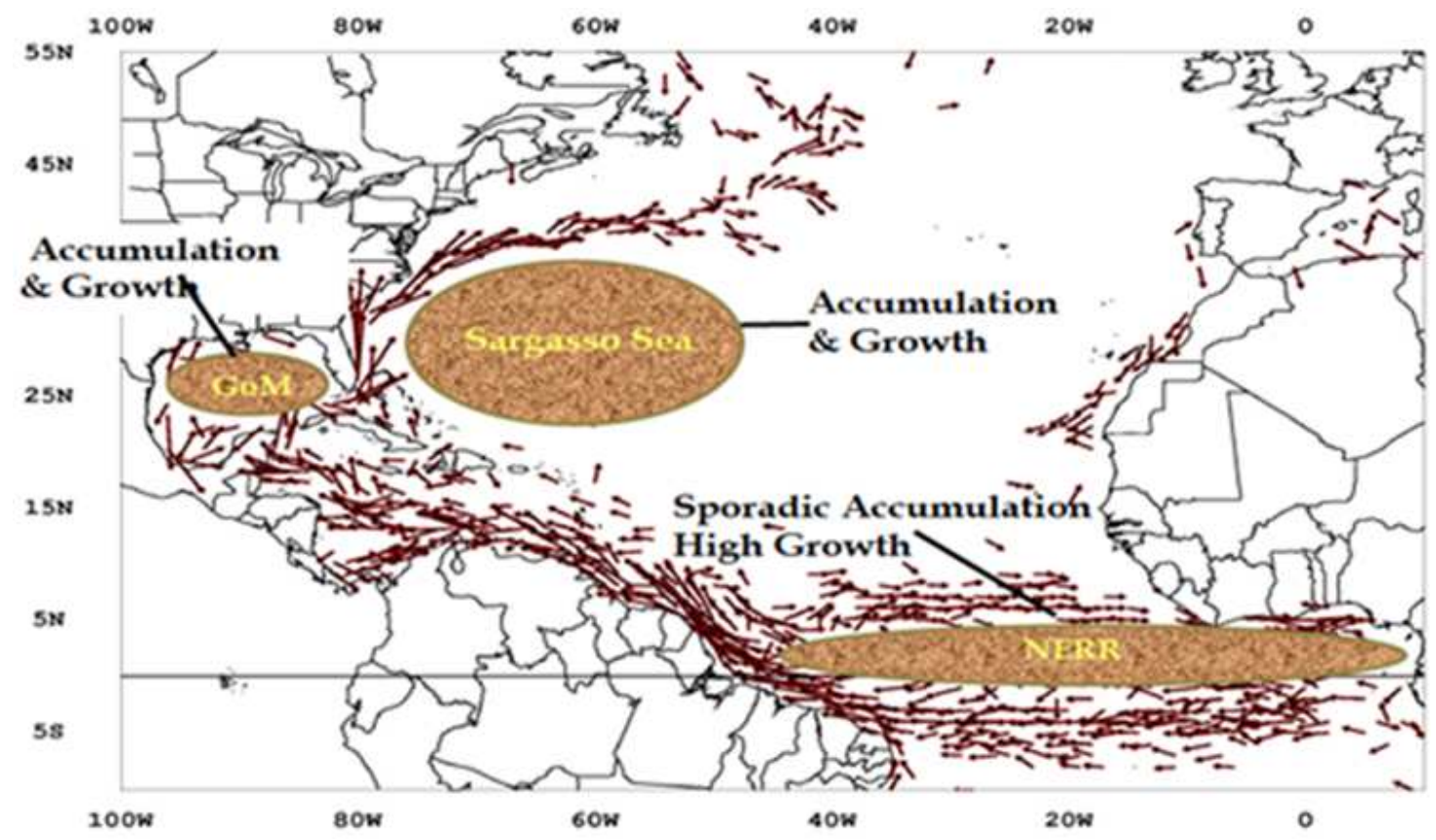

Fig. 3. Growth and Accumulation of Sargassum in the region - Sources: The regions of accumulation and algae growth in the Atlantic Ocean (Derilus et al., 2014; Johnson et al., 2013)

\section{Potential Impacts of the Sargassum Invasion}

Significant economic, environmental and health impacts have been attributed to the Sargassum Invasion in the region. These severe influxes are "harmful algal blooms" that can lead to fish kills, beach fouling, tourism losses and even coastal dead zones (Lopez et al., 2998). The tourism industry, on which the region depends heavily, has taken a serious hit (Defenders of Wildlife, 2010). The foul smell generated by decomposing Sargassum, along with the proliferating biting sand fleas, have forced tourists to stay away from these usually pristine waters (http://www.dailymail.co.uk/travel/travel_news/article3315178/EARTHPRINTS-Transformation-Mexicanvacation-hotspot-comes-price.html). From Barbados to the Dominican Republic and Mexico, all countries affected by the Sargassum invasion are experiencing unforeseen cancellations during the heavy tourist season (http://www.theguardian.com/environment/2015/aug/10/ caribbean-bound-tourists-cancel-holidays-due-to-foul- 
smelling-seaweed). Not only they are losing revenues due to the invasion, but also it costs them money to clean these beaches (http://www.theguardian.com/environment/2015/aug/10/ caribbean-bound-tourists-cancel-holidays-due-to-foulsmelling-seaweed). From the Dominican Republic in the north, to Barbados in the east and Mexico's Caribbean resorts to the west, officials have authorized emergency money to fund cleanup efforts and clear stinking mounds of seaweed that in some cases have piled up nearly 10 feet high on beaches, choked scenic coves and cut off moored boats (http://www.theguardian.com/environment/2015/aug/10/ caribbean-bound-tourists-cancel-holidays-due-to-foulsmelling-seaweed). In Cancun, Mexico alone, the authorities estimate that the cleaning of each meter of coastline could range as high as a $\$ 1000.00$. They have budgeted almost $\$ 10$ million and hired approximately 5000 temporary workers to remove the seaweed that engulfed the Caribbean coast of Mexico (Hoang et al., 2016). The island of Tobago has even declared a state of natural disaster (http://ambergriscaye.com/forum/ubbthreads.php/topics/ 506881/the-journey-of-the-sargassum.html). Some officials are calling for an emergency meeting of the 15nation Caribbean Community, worried that the worsening seaweed influx could become a chronic dilemma for the globe's most tourism-dependent region (http://ambergriscaye.com/forum/ubbthreads.php/topics/ 506881/the-journey-of-the-sargassum.html).

When it comes to public health, although these algae are either venomous nor allergenic, it is not advisable to bathe in beaches with high concentrations of algae. There is at this stage an elevated risk of drowning (http://www.nytimes.com/2011/10/16/travel/caribbeanbeaches-dig-out-from-massive-seaweed-invasion.html). The presence of rafts of algae in the sea can also be havens for some marine species that can cause irritation upon contact (http://ambergriscaye.com/forum/ubbthreads.php/topics/ 506881/the-journey-of-the-sargassum.html). In addition, under certain climatic conditions, the decomposition of algae on the beaches causes the release of Hydrogen Sulfide $\left(\mathrm{H}_{2} \mathrm{~S}\right)$ gas, responsible also for the foul odor of "rotten eggs" (Oyesiku and Egunyomi, 2014). Hydrogen sulfide is in fact a toxic gas, however its level of toxicity is a function of the inhaled dose and the duration of exposure. $\mathrm{H}_{2} \mathrm{~S}$ is likely to cause, even at low doses, irritation of the eyes and respiratory tract. Therefore, people suffering from respiratory diseases (respiratory failure, asthma, chronic bronchitis, etc.) must avoid areas of stranded algae in a state of decomposition. $\mathrm{H}_{2} \mathrm{~S}$ is detectable at a concentration of $0.05 \mathrm{ppm}$, it can serve as a warning signal. But when the concentration reaches the threshold of 50 to $150 \mathrm{ppm}$, it paralyzes the olfactory nerve and at $300 \mathrm{ppm}$ we lose consciousness. The maximum acceptable threshold in a medium is $10 \mathrm{ppm}$ and a concentration of $50 \mathrm{ppm}$ require immediate evacuation. Although the collection of fresh algae is harmless, the collection of rotting algae should be treated more cautiously by professionals equipped with masks to protect against $\mathrm{H}_{2} \mathrm{~S}$ gases (Agence Régionale de Santé Martinique, 2011). In other jurisdictions, including France and China, $\mathrm{H}_{2} \mathrm{~S}$ produced by decomposing algae on beaches have killed both humans and farm animals (Oyesiku and Egunyomi, 2014; Revue de presse «Caraïbes» (2015)).

\section{On the Environmental Front}

The presence of Sargassum in water can be very useful for certain species, as it provides food and shelter for some marine species (lionfish, young sea turtles, tuna, kingfish) (Lopez et al., 2008). As stated in the Defenders of Wildlife in 2010 "Sargassum is also a vital nursery for newly fledged sea turtles that are especially vulnerable to ocean-going predators" (Defenders of Wildlife, 2010). Under certain conditions, the presence of algae on the beaches can help fight beach erosion (Bruun, 1983). This was demonstrated in Bruun 1983, where beach stability was heavily affected upon removal of invading Sargassum (Bruun, 1983). But, at high concentrations, Sargassum may negatively affect marine flora and fauna located near the coast. The accumulation of algae on the water surface prevents light penetration (Lopez et al., 2008). Therefore, seagrasses and corals are affected by the lack of light necessary for photosynthesis (Lopez et al., 2008). On the beaches, algae disturb nesting sea turtles and make it difficult, if not impossible, for the movement of baby turtles from the shore to open water (Lopez et al., 2008; Bruun, 1983). The massive Sargassum beaching is becoming a major source of harm to coastal environments. Cleanup efforts by work crews may also worsen beach erosion. In addition, the decomposition of algae may lead to the alteration of water chemistry which subsequently causes the death of certain fish species susceptible to falling oxygen levels (Hoang et al., 2016).

\section{How can we turn this Problem into Opportunities?}

In terms of energy value, Sargassum like any other type of biomass represent attractive opportunities (Gervais and Marty, 2014). Sargassum can be converted to biogas via anaerobic digestion. Biogas made predominantly of methane, has a high-energy value, that can be used to meet many of our energy needs (Gervais and Marty, 2014).

The feasibility of this process is currently being tested in the CRES laboratory at the University of Puerto Rico Rio Piedras (CRES-Center for Renewable Energy and Sustainability). Experiments have shown that for every $\mathrm{Kg}$ of total dried solids of algae fed to a bioreactor, a biogas (mixture of methane and carbon dioxide, etc ...: Energy sources) equivalent of $50 \mathrm{~L}$ was generated, whose composition in methane is greater 
than $55 \%$, with an excellent $\mathrm{CH} 4 / \mathrm{CO}_{2}$ ration of $2: 1$ (De La Rosa-Acosta et al., 2015). These studies were conducted in two 15L bioreactors at different salinities (10 and 35 ppt seawater). Biogas production yield, in the $10 \mathrm{ppt}$ was higher than in the $35 \mathrm{ppt}$ due to the presence of two inhibitors (sodium and sulfur) of methanogenic organisms present in the $35 \mathrm{ppt}$ seawater (Fortuné et al., 2015). The $35 \mathrm{ppt}$ bioreactor produced $67 \mathrm{~mL} \mathrm{~b} / \mathrm{g}$ per gTS*d which is 67 liters of biogas per $\mathrm{kg} \mathrm{TS} / \mathrm{d}$. The $10 \mathrm{ppt}$ bioreactor produced $83 \mathrm{ml} \mathrm{b} / \mathrm{g}$ per gTS*d which is the same as $83 \mathrm{~L} \mathrm{~b} / \mathrm{g}$ per $\mathrm{gTS} * \mathrm{~d}$ (Fortuné et al., 2015). Indeed, it has been demonstrated that it is possible to produce biogas from Sargassum using seawater, which is abundantly available taking thereby pressure off limited fresh water resources (Gervais, 2014). Since fresh water has a cost for washing the seaweed prior to use and also in the preparation of bioreactor feedstock, the use of sea water seems to be an attractive option for the production of biogas in island jurisdictions such as Puerto Rico where we face limitations on freshwater supplies. But we must consider the choice of materials for the manufacture of digesters due to salt corrosion.

Sargassum displayed tremendous benefits as soil amendment (McHugh, 2003). When used as an organic nutrient-rich fertilizer (Fig. 4), Sargassum appeared to increase not only crop yield, but also soil characteristics (McHugh, 2003). In a study conducted at the University of Puerto Rico CRES laboratory, after transformation into biogas in an anaerobic system, the effluents from the bioreactors were tested and proven to be excellent sources of nutrients. Results from these studies revealed, that even considering the low NPK content of the effluents, $(\mathrm{N}: 6.3 \mathrm{mg} / 100 \mathrm{~g}$; P: 96.5 $\mathrm{mg} / 100 \mathrm{~g}$ and $\mathrm{K}: 28 \mathrm{mg} / 100 \mathrm{~g}$ ), Sargassum outperformed inorganic fertilizer and therefore was recommended as fertilizer (McHugh, 2003). From these findings, it can be concluded that a high percentage of NPK does not necessarily mean better fertilizer. The total NPK of Sargassum although generally lower compared to conventional fertilizers, seems to be assimilated by plants more effectively as slow release nutrients. In addition, as previously demonstrated (Kumari et al., 2013; Roberts et al., 2015), organic fertilizers seem to increase the organic matter content, the soil structure and moisture storage capabilities of soils. Finally, it is recommended that the excess salt in Sargassum be removed before use for agricultural purposes in order to avoid soil salinization and groundwater pollution. The mouths of rivers e.g., can be used to remove excess salt from algae by simply washing the harvested algae prior to processing as fertilizer production. The exposure of algae to rain after collection next to the beach will also remove some of the existing salt. Some advantages of Sargassum as organic fertilizers are listed below (McHugh, 2003).

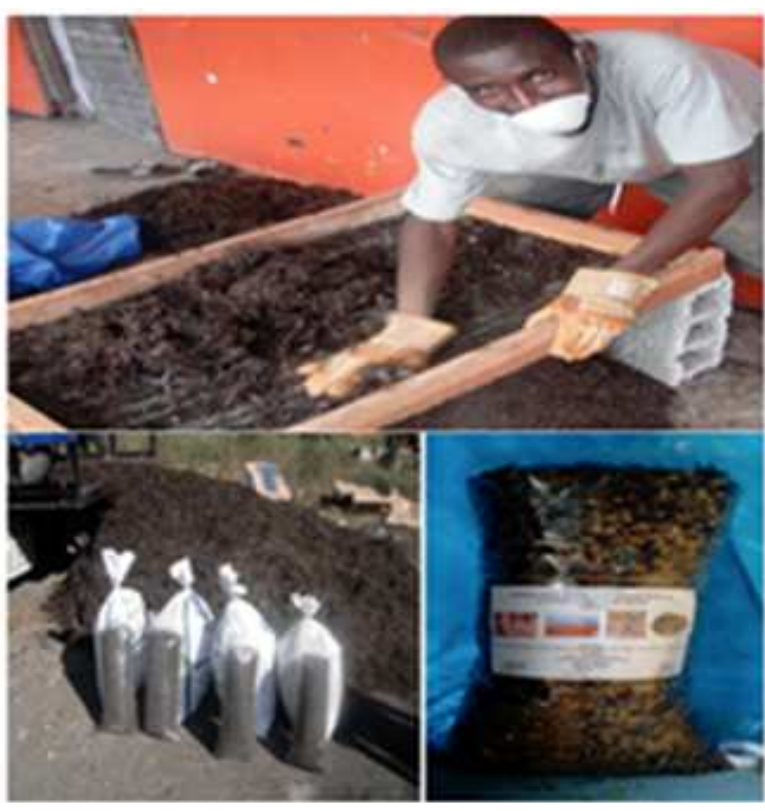

Fig. 4. Production of organic fertilizer from Sargassum (By Georges Valme, Leogane Haiti)

Algae extracts and algae have been shown to:

- Improve water holding capacity

- Promote the growth of beneficial soil microbes

- Promote root growth and development

- Improve the absorption of nutrients through the roots

- Increase fruit yield

- Promote rooting cuttings

- Encourage abiotic stress tolerance in plants

- Improve protection against pests and diseases (nematodes, fungal and bacterial pathogens)

Furthermore, Sargassum can be ground into a more or less fine powder and mixed in proportion of 15 to $20 \%$ with other carbon sources (biomass) to produce charcoal briquettes (Gervais and Marty, 2014). In many countries, trees are being harvested on a large scale in the processing of cooking charcoal, leading to massive deforestation. Processing the Sargassum into briquettes will provide an attractive and economically viable alternative to charcoal production from wood.

\section{Conclusion}

The Sargassum invasion of Caribbean, African and the Gulf of Mexico beaches is a recent phenomenon that is most likely due to the impact of human activities on marine ecosystems. Global Climate Change and the concomitant higher than normal temperatures are currently being looked at as the main driver. There is 
yet no scientific consensus on the origins of this problem and how to address the specific causes with the goal of redressing this natural catastrophe. In the meantime, the accumulation of these algae on beaches continues to have a tremendous impact on tourism in the region, as well as on the balance of the marine ecosystems and even on the health of affected local populations. However, this unprecedented invasion seems to offer several economic opportunities in the energy and agricultural sector. This macroalgae can in fact be transformed into biogas and biocoal as an energy source or organic fertilizer for plant health and soil amendment. Ultimately, these newly discovered characteristics of Sargassum will partly help us redress some of the environmental issues brought about by Global Climate Change. Now it is the time to turn this problem into opportunities.

\section{Acknowledgment}

This work was supported by the United States Agency for International Development under Grant $<$ AID-OAA-A-11-00012>; and The US Department of Defense, under Grant $<$ DOD-AF-11427384>.

\section{Author's Contributions}

Gary Gervais and Jodany Fortune: Conceived and designed the experiments.

Clifford Louime: Contributed reagents/materials/analysis tools and wrote the paper.

\section{Conflicts of Interest}

The authors declare no conflict of interest. The founding sponsors had no role in the design of the study; in the collection, analyses, or interpretation of data; in the writing of the manuscript and in the decision to publish the results.

\section{References}

Agence Régionale de Santé Martinique, 2011. Algues Sargasses: Un risque sanitaire? Cellule Communication Newsletter No11.

Bruun, P., 1983. Beach scraping - is it damaging to beach stability? Coastal Eng., 7: 167-173. DOI: 10.1016/0378-3839(83)90011-X

De La Rosa-Acosta, M., D. Derilus, M. Morales-Medina, J. Fortuné and G.W. Gervais, 2015. Comparison of Different Methods to Measure Organic Matter Content in Feedstock and Effluents of a Saline Anaerobic Bioreactor for Biogas Production. Poster presentation at the annual undergraduate research symposium, Universidad del Este, Carolina, Puerto Rico.
Defenders

of

Wildlife,

2010. http://www.defenders.org/sites/default/files/publicati ons/wildlife_and_offshore_drilling_sargassum.pdf

Doyle, E. and J. Franks, 2015. Sargassum Fact Sheet. Gulf and Caribbean Fisheries Institute.

Derilus, D., E.S. Massey, G.W. Gervais and C. Louimé, 2014. Characterization of the structure and dynamics of microbial communities in seawater anaerobic bioreactors using 454 pyrosequencing of 16s ribosomal RNA. Proceedings of the 4th International Conference on Algal Biomass, Biofuels and Bioproducts, (BBB' 14), Santa Fe, NM.

Fortuné, J., A. Forestil and G.W. Gervais, 2015. Nutrient flows and recovery in multistage anaerobic bioreactors fed with Sargassum spp. Proceedings of the 50th ACS Junior Technical Meeting and 35th Puerto Rico Interdisciplinary Scientific Meeting, (ISM' 15), University of Puerto Rico, Rio Piedras Campus, PR.

Gavio, B., M.N. Rincón-Díaz and A. Santos-Martínez, 2015. Massive quantities of pelagic Sargassum on the shores of San Andres island, Southwestern Caribbean. Acta Biol. Colomb., 20: 239-241. DOI: $10.15446 /$ abc.v20n1.46109

Gervais, G. and M. Marty, 2014. Las Algas Marinas y la conversion de su mas cruda a combustible. University of Puerto Rico. El Centro de Energía Renovable.

Gervais, G.W., 2014. Do we have enough Marine real Estate to produce biofuels for Puerto Rico? Proceedings of the Annual Meeting of the Puerto Rico Chapter of AAAS, (AAAS' 14), Universidad del Turabo, Caguas, PR.

Gower, J. and S. King, 2008. Satellite images show the movement of floating Sargassum in the Gulf of Mexico and Atlantic Ocean. Nature Precedings.

Gower, J., E. Young and S. King, 2013. Satellite images suggest a new Sargassum source region in 2011. Remote Sens. Lett., 4: 764-773. DOI: $10.1080 / 2150704 X .2013 .796433$

Gower, J.F.R. and S.A. King, 2011. Distribution of floating Sargassum in the Gulf of Mexico and the Atlantic Ocean mapped using MERIS. Int. J. Remote Sens., 32: 1917-1929. DOI: $10.1080 / 01431161003639660$

Hoang, T.C., A.J. Cole, R.K. Fotedar, M.J. O'Leary and M.W. Lomas et al., 2016. Seasonal changes in water quality and Sargassum biomass in southwest Australia. Mar. Ecol. Prog. Ser., 551: 63-79. DOI: $10.3354 /$ meps 11735

http://ambergriscaye.com/forum/ubbthreads.php/topics/5 06881/the-journey-of-the-sargassum.html

http://coastalcare.org/sections/inform/page/4/ 
http://www.dailymail.co.uk/travel/travel_news/article3315178/EARTHPRINTS-TransformationMexican-vacation-hotspot-comes-price.html

http://wwz.ifremer.fr/guyane/content/download/41806/5 69470/file/Sargasses\%20Guyane.pdf

http://www.newsweek.com/2015/07/10/sargassumruining-beaches-texas-tobago-347735.html

http://www.nytimes.com/2011/10/16/travel/caribbeanbeaches-dig-out-from-massive-seaweedinvasion.html

http://www.theguardian.com/environment/2015/aug/10/c aribbean-bound-tourists-cancel-holidays-due-tofoul-smelling-seaweed

Johnson, D.R., D.S. Ko, J.S. Franks, P. Moreno and G. Sanchez-Rubio, 2013. The sargassum invasion of the Eastern Caribbean and dynamics of the Equatorial North Atlantic. Proceedings of the 65th Gulf and Caribbean Fisheries Institute, Nov. 5-9, Santa Marta, Colombia, pp: 102-103.

Kumari, R., I. Kaur and A.K. Bhatnagar, 2013. Enhancing soil health and productivity of Lycopersicon esculentum Mill. Using Sargassum johnstonii Setchell and Gardner as a soil conditioner and fertilizer. J. Applied Phycol., 25: 1225-1225. DOI: $10.1007 /$ s10811-012-9933-y

Laffoley, D.D.A., 2011. The Protection and Management of the Sargasso Sea: The Golden Floating Rainforest of the Atlantic Ocean. Summary Science and Supporting Evidence Case, Sargasso Sea Alliance, pp: 44.

Le Lann, K., 2009. Etude de la biodiversite des Sargassaceae (Fucales, Phaeophyceae) en milieu temperere et tropical: Ecologie, chimiotaxonomie et source de compostes bioactifs. Other [q- bio.OT]. Universite de Bretagne occidentale.

Lopez, C.B., Q. Dortch, E.B. Jewett and D. Garrison, 2008. Scientific assessment of Marine Harmful Algal Blooms. Interagency Working Group on Harmful Algal Blooms, Hypoxia and Human Health of the Joint Subcommittee on Ocean Science and Technology. Washington, D.C.
McHugh, D.J., 2003. A guide to the Seaweed Industry. Other uses of Seaweeds, FOA Technical Paper, School of Chemistry, University College Univer.

Moanga, D.A., 2015. Karenia brevis hot spots in the west Florida shelf and their associated socioeconomic implications. MS Theses, University of Miami.

Moreira, A. and G. Alfonso, 2013. Inusual arribazón de Sargassum fluitans (Børgesen) Børgesen en la costa centro-sur de Cuba. Rev. Invest. Mar., 33: 17-20.

Oyesiku, O.O. and A. Egunyomi, 2014. Identification and chemical studies of pelagic masses of Sargassum natans (Linnaeus) Gaillon and $S$. fluitans (Borgessen) Borgesen (brown algae), found offshore in Ondo State, Nigeria. African J. Biotechnol., 13: 1188-1193.

DOI: $10.5897 / A J B 2013.12335$

Revue de presse «Caraïbes » (2015): L'invasion des sargasses Guadeloupe http://joannacaira.mondoblog.org/tag/algues

Roberts, D.A., N.A. Paul, S.A. Dworjanyn, M.I. Bird and R, de Nys, 2015. Biochar from commercially cultivated seaweed for soil amelioration. Sci. Rep., 5: 9665-9665. DOI: 10.1038/srep09665

Sargeant, P.G., 2015. What you need to know about Sargassum invading the Caribbean. https://www.linkedin.com/pulse/what-you-needknow-sargassum-invading-caribbean-sargeant-gsm

Smetacek, V. and A. Zingone, 2013. Green and golden seaweed tides on the rise. Nature, 504: 84-88. DOI: $10.1038 /$ nature 12860

Valesco, A., 2015. Sargazo invade el Caribe: ¿Qué es y cómo se combate? El Financiero, Mexico: http://www.elfinanciero.com.mx/nacional/sargazoinvade-el-caribe-que-es-y-como-se-combate.html 